den Betrachtungsweise: Territorialitätsprinzip oder Gründungs- bzw. Sitztheorie als "sinnvoller Anknüpfungspunkt" für rechtliche Exportkontrollmechanismen; Wirkungs- ("effective doctrine"), Schutz-, Universalitäts- oder Nationalitätsprinzip für Reexportkontrolle und den dabei unterschiedlichen Schwerpunkten verpflichteten Ansätzen des anglo-amerikanischen und deutschen Rechts. Auch neue Tendenzen, etwa die sog. Unterwerfungserklärung oder eine "Ursprungstheorie" für Technologiegüter werden erörtert. Für zu erwartende Jurisdiktionskonflikte erhofft sich die Verfasserin von der Diskussion um den UN Code of Conduct for Transnational Corporations (Para. 58: "Respektierung von Staatsinteressen") und einer unparteiischen Abwägung internationaler Sachverhalte durch nationale Gerichte neue Entwicklungen des Wirtschaftsrechts.

Mit diesem Ausblick endet Puttlers tour d'horizon, die damit eindrucksvoll den Meinungsstand bis 1988 zusammengefaßt und Denkansätze über das Erscheinungsjahr hinaus geliefert hat.

Niels Lau

\title{
Thomas M. Franck
}

\section{The Power of Legitimacy Among Nations}

Oxford University Press, New York / Oxford 1990, 303 S.

"Where is the John Stuart Mill of international libertarian theory?" (14) Mit dieser Frage beklagt Thomas M. Franck eingangs seines hier angezeigten Buches die Vernachlässigung rechts- und allgemeinphilosophischer Fragestellungen, die sich angesichts des gegenwärtigen Wandels in den internationalen Beziehungen ergeben. Natürlich beansprucht er nicht, diese Rolle selbst zu übernehmen - für das vorliegende Buch wäre dieser Anspruch auch zu hoch gegriffen. Gleichwohl legt er eine nützliche und gedankenanregende Untersuchung über die Rolle der Legitimität in den internationalen Beziehungen vor.

Problematisch ist, daß der zentrale Begriff der "Legitimität", trotz der dahingehenden Bemühungen in der Einleitung, nicht ganz genau bestimmt wird. Im deutschen Sprachraum scheint mir die einschlägige Diskussion unter den Begriffen Legalität, Legitimität und Moralität bzw. Gerechtigkeit geführt worden zu sein, wobei Legitimität die Neigung hat, mit Gerechtigkeit zu verschmelzen. Franck setzt die Akzente in dieser Trias etwas anders. Den Begriff "Legalität" reserviert er praktisch für innerstaatliche Normen, die durch eine zentrale Autorität gesetzt und sanktionsbewehrt sind. Da dies bei internationalen Normen (Franck nennt sie lieber "rules") nicht der Fall ist und auch sonst die Wirkungsweise internationaler Normen und Regeln sich von der innerstaatlichen Rechts unterscheidet, zieht Franck es vor, gar nicht von internationalem Recht zu sprechen. Dagegen liegt ihm sehr daran zu zeigen, daß das internationale System heute "a functioning community with a 
concept of obligation" ist (206). Legitimität, am ehesten zu umschreiben als formelle oder Verfahrensgerechtigkeit, ist für diese "community" grundlegend.

"What observable characteristics of a norm or rule of conduct increase its legitimacy?" (50) Die Beantwortung dieser Frage macht den Hauptteil des Buches aus. Vier Elemente, die Legitimität fördem, werden in insgesamt acht Kapiteln diskutiert: die "determinacy", die wesentlich mit einer präzisen Formulierung der Verhaltensvorschriften zusammenhängt; "symbolic validation", bei der es um die ehrwürdigen und damit legitimitätsfördernden Normsetzungsverfahren geht (Franck spricht hier auch vom "pedigree" von Normen); "coherence", also der systematische Zusammenhang zwischen Norm, Normzweck und grundlegenden Prinzipien; und schließlich "adherence", "by which is meant the vertical nexus between a primary rule of obligation ... and a hierarchy of secondary rules identifying the sources of rules and establishing normative standards that define how rules are to be made, interpreted, and applied." (184) Die Ausführungen hierzu sind inhaltlich überwiegend einleuchtend, die Zahl und Breite der Beispiele macht sie jedoch etwas schwerfällig. Auch zeigen die Fußnoten, daß Franck die relativ breite sozialwissenschaftliche Literatur der vergangenen Jahre über Normentstehung und -wirkung zwar kennt, er selbst bleibt jedoch einer stark impressionistischen Darstellung verhaftet.

Das wohl interessanteste Kapitel ist das letzte, in dem Franck begründet, warum Legitimität im intemationalen System zwar unerhört wichtig ist, warum jedoch die verwandte (nämlich auch freiwillige Normbefolgung fördernde) und dennoch strikt zu trennende Gerechtigkeit auf intemationaler Ebene auf absehbare Zeit nur eine geringe Rolle spielt. Seine Unterscheidung beider Begriffe macht am besten ein von ihm selbst angeführtes Beispiel deutlich. Man stelle sich eine säkulare Gemeinschaft von 100 Personen vor, die aus zehn gleichgroßen Gruppen von Anhängern zehn verschiedener Religionen besteht. "In such circumstances, a secular social contract among all 100 persons which simply prohibits the establishment of any religion, is likely to exercise a powerful pull towards compliance based on general recognition of its legitimacy, even though none of the parties would regard the rule as reflecting the most morally desirable principle." (244) Gerade auf internationaler Ebene sind die traditionell-religiös begründeten Moralvorstellungen sehr divergent, und deshalb liegt es im Interesse aller, zumindest eine säkulare Gemeinschaft, wie sie das Staatensystem heute darstellt, zu erhalten, auch wenn dieses Staatensystem auf der Ebene der Individuen, auf der allein nach Franck das Kriterium der Gerechtigkeit anwendbar ist, vielfach ungerechte Wirkungen zeitigt. Doch stehen Legitimität und Gerechtigkeit auch im internationalen System nicht ganz unverbunden nebeneinander. "If legitimacy must understand the value of justice as an ally in legitimacy's quest for predictability and stability, justice must likewise understand the importance of legitimacy as a tool in preserving a socio-political framework within which justice eventually can be done." (244) "Justice, it may be said, redeems the social contract, in somewhat the way the New Deal is said to have saved capitalism" (239), schreibt Franck kurz zuvor. Es ist nicht sein geringstes Verdienst, damit nach guter gedanklicher Vorbereitung noch einmal die Frage aufzuwerfen 
(wenn auch nicht zu beantworten), was dies für das internationale System konkret bedeutet. Es liegt an uns allen, eine adäquate Antwort zu finden.

Martin List

Standing Committee for Standard Contracts of the European Association for Chinese Law (ed.)

Equity Joint Ventures with Chinese Partners - Practical Alternatives

Nomos Verlagsgesellschaft, Baden-Baden 1991, 354 S., DM 118,--

After the demise of Mao Zedong in 1976 and the fall from power of his cabal in that same year, China's self-sufficient autarchy in Mao's mould has, in particular since 1979, been replaced by the pragmatic autarchy of the re-emerging Deng Xiaoping and those around him who favour vigorous use of foreign economic input in the colossal effort of the "Four Modemisations" (Scil of Agriculture, industry, defence and science and technology), that latest leg in China's quest to regain the "wealth and power" so dramatically lost to foreign powers and intruders in the XIXth and early XXth centuries.

A key element in Deng's policy of "reform and opening" since 1979 has been the attraction of foreign investment in order to add modem capitalist money, know-how and exporting expertise to domestic efforts at becoming competitive in international commerce. Equity joint ventures are the comerstone of this strategy as they permit injection into the orthodox command economy of the whole panoply of business practices from overseas marketoriented industrial environments. In spite of inevitable initial difficulties in blending often radically different attitudes and interests, the growth of foreign investment in China has been spectacular: Today thousands of joint ventures are operating in China, in the main with partners from Hong Kong and Taiwan, but including also numerous big names from advanced industrialised countries whose entrepreneurs seek long-term foothold in a promising domestic Chinese market or the shorter-term benefits of preferential tax treatment and low labour costs for China-based manufacture intended for (re-)export.

The Chinese legal framework for the operation of Sino-foreign equity joint ventures has gone through several revisions since the enactment of the first law on equity joint ventures in 1979, notably adding wholly foreign-owned ventures in China to the catalogue of legal models on offer to the outside investor.

The present work presents the contributions of twelve practising lawyers who have been professionally involved in China-related business during the "reform and openig" decade since 1979. The have taken the 1985 "Sample Articles of Association for Joint Ventures Using Chinese and Foreign Investment" and the "Sample Contract for Joint Ventures Using 